\title{
EDITORIAL DE LANÇAMENTO
}

\author{
Manoel Raimundo Santana Farias \\ manoel.farias@fipecafi.org \\ Editor
}

\section{Prezados leitores}

Com grande satisfação apresento a Revista Fipecafi de Contabilidade, Controladoria e Finanças, mantida pela Fundação Instituto de Pesquisas Contábeis, Atuariais e Financeiras (Fipecafi), com suporte da Diretoria de Pesquisa e da Coordenação do Mestrado Profissional em Controladoria e Finanças da Fipecafi.

A Revista Fipecafi de Contabilidade, Controladoria e Finanças tem como missão divulgar conhecimento científico e tecnológico das áreas de contabilidade, administração, finanças, atuária e afins aplicado à realidade de organizações públicas, privadas e do terceiro setor.

O escopo da revista abrange cinco eixos temáticos: 1) Evolução tecnológica, educação e inovação em negócios, contabilidade e gestão; 2) Contabilidade gerencial e controladoria; 3) Contabilidade financeira, auditoria e tributação; 4) Contabilidade governamental e terceiro setor; 5) Finanças, mercado de capitais e atuária.

A periodicidade da revista é quadrimestral. Todo seu conteúdo é de acesso aberto e os artigos são disponibilizados em meio eletrônico para download no formato PDF. Seu processo editorial é totalmente eletrônico, em fluxo contínuo de aceite de submissão de artigos para avaliação e publicação, quando aprovado por pelo menos dois avaliadores em processo de avaliação às cegas, ou blind review. As informações aos leitores estão disponíveis e podem ser acessadas no website da revista sem necessidade de cadastro, exceto se autores e avaliadores.

Esta edição de lançamento é composta por cinco artigos de autores convidados, com perfil de especialista e atuação acadêmica e/ou profissional destacada nos temas escritos, os quais apresento a seguir.

O primeiro artigo - Goodwill: baixa, amortização ou impairment? E quando originado dopassivo?-, de autoria de Eliseu Martins, trata de um temasobrecontabilidade financeira em padrão internacional, com grande impacto no reconhecimento e na mensuração dos elementos patrimoniais e de resultado de empresas e grupos econômicos envolvidos em combinações de negócios, com discussão em andamento no âmbito das normas de contabilidade e, portanto, extremamente relevante aos preparadores das demonstrações contábeis e aos usuários da informação contábil gerada e divulgada pelas empresas.

O segundo artigo - Beyond covid-19: o que os gurus têm a dizer para a gestão? -, de autoria de Fábio Frezatti, traz uma análise crítica das forças que podem afetar a gestão das organizações após a pandemia, discute crise organizacional e ressalta que uma organização que não resolveu problemas de sua crise, em uma crise estrutural macro, como a covid-19, terá ainda mais dificuldades. Sem dúvida, uma questão em andamento e que está afetando profundamente tanto as organizações públicas quanto as privadas.

No terceiro artigo - Contabilidade e tributação: diferenças na apuração do lucro, prática contábil e pesquisa -, os autores Alexandre Evaristo Pinto, Fábio Pereira da Silva e Paulo Henrique Pêgas abordam a prática contábil e ressaltam os temas de pesquisa no âmbito da interface entre contabilidade e tributação, discutindo as diferenças entre o lucro contábil e o fiscal e a evidenciação contábil dos tributos correntes e diferidos 
sobre o lucro e dos tratamentos tributários incertos. Esse tema é muito relevante aos negócios, dada a relação entre contabilidade tributária e contabilidade financeira, com os respectivos efeitos nas informações contábeis e nas decisões das empresas.

No quarto artigo - A mensuração de eventos: uma contribuição do modelo de gestão econômica -, os autores Carlos Alberto Pereira, Edgard Bruno Cornacchione Junior e Reinaldo Guerreiro, a partir de uma revisão da literatura relevante e atual, destacam contribuições do modelo de gestão econômica (Gecon), como a mensuração de resultado por área de responsabilidade, discutem uma contribuição específica do modelo, a mensuração de eventos econômicos, e indicam que o Gecon influenciou e ainda influencia o campo acadêmico e a prática empresarial. Nesse sentido, oriundo de pontes entre a academia e a prática, o artigo indica as potencialidades que se têm à prática e às pesquisas futuras.

No quinto artigo - Doze anos de convergência das normas brasileiras às IPSAS: avanços e limites das pesquisas -, as autoras Maiara Sasso e Patrícia Siqueira Varela, a partir da revisão das pesquisas relevantes e atuais da contabilidade aplicada ao setor público, abordam profundamente aspectos essenciais para pesquisas voltadas à normatização e à prática contábil no setor público e indicam que o Brasil, em pleno processo de convergência da contabilidade governamental às normas internacionais, é um campo fértil ao desenvolvimento de conhecimento científico aplicado e ao engajamento de pesquisadores e profissionais com grande potencial de impacto na academia e na prática das organizações públicas.

Agradeço à Diretoria e ao Conselho Curador da Fipecafi, aos autores, à equipe técnica da revista e desejo a todos uma ótima leitura.

\section{EQUIPE EDITORIAL}

\section{EDITOR}

Manoel Raimundo Santana Farias - Professor da Fipecafi, Doutor em Ciências Contábeis pela Universidade de São Paulo.

\section{CONSELHO DE POLÍTICA EDITORIAL}

Welington Rocha - Presidente da Fipecafi, Doutor em Controladoria e Contabilidade pela Universidade de São Paulo.

Fernando Dal-Ri Múrcia - Diretor de Pesquisa da Fipecafi, Doutor em Ciências Contábeis pela Universidade de São Paulo.

Paschoal Tadeu Russo - Coordenador do Mestrado da Fipecafi, Doutor em Ciências Contábeis Universidade de São Paulo.

Reinaldo Guerreiro - Presidente do Conselho Curador da Fipecafi, Doutor em Controladoria e Contabilidade pela Universidade de São Paulo. 